\title{
PROTEIN, ENZYME, AND ISOENZYME DISTRIBUTION IN HUMAN SERUM FRACTIONS OBTAINED BY ULTRACENTRIFUGATION
}

\author{
ELIZABETH L. PRUDEN, PAUL L. CREASON, MARILYN T. CREASON \\ Caylor-Nickel Research Foundation, Blufton, Ind.
}

AND WALTER D. BLOCK

Departments of Dermatology, School of Medicine and Health Development, School of Public Heallh, University of Michigan, Ann Arbor, Mich. (U.S.A.)

(Received January 8, 1968)

SUMMARY

We have described the protein, enzyme, and isoenzyme characteristics of three gross fractions of both normal and abnormal human sera, as obtained by application of high centrifugal force. In the absence of solution gradient, such fractions represent pure and undiluted elements of the serum; they are reproducible and sufficiently voluminous for extensive analytical study. Specific features of these fractions may be of interest in planning additional or peripheral investigations of serum. Fraction I appears to be a fair sample of native serum water; Fraction II appears to segregate the pre- $\beta$-globulin lipoprotein component observed in some sera; Fraction III is a concentrated solution of LDH, CPK, and SGOT enzymes, and $\gamma$-globulin-rich protein, which is lipoprotein-free. More than $95 \%$ of the LDH, CPK, and SGOT is located in Fractions II and III. Quantitative activity and qualitative nature of these enzymes appears to survive the stress of the ultracentrifuge technique relatively well.

In $196 \mathrm{x}$, Breen and Freeman ${ }^{1}$ obtained, by application of high centrifugal force in the absence of solution gradient, three separate fractions of human plasma, which they called Fractions I, II, and III. They utilized the protein-poor top layer, Fraction $\mathrm{I}$, for determination of unbound calcium. In studies of calcium metabolism, using a modified ultracentrifuge technique, we have had occasion to characterize further all three fractions from both normal and abnormal sera. This paper will report our observations of protein, enzyme, and isoenzyme distribution in such fractions.

\section{MATERIALS AND METHODS}

\section{Specimens}

Serum specimens were obtained one or two at a time by bleeding healthy voluntecrs and persons with limb-girdle muscular dystrophy. The fresh whole serum was analyzed promptly for total protein, calcium, magnesium, serum glutamic oxalo- 
acetic transaminase (SGOT), lactic dehydrogenase (LDH), and creatine phosphokinase (CPK), and was subjected to protein and lipoprotein electrophoresis. Within $48 \mathrm{~h}$ after collection, the whole serum was ultracentrifuged. Fifteen milliliters of serum were divided equally among three polypropylene tubes, which were centrifuged simultaneously in a Model L-2* preparative ultracentrifuge, rotor $\# \mathrm{SW}_{30} \mathrm{~L}$, for $\mathrm{i}_{7} \mathrm{~h}$ at $170000 \mathrm{~g}$ and $30^{\circ}$. The three discrete layers which appeared were carefully and separately aspirated with fine tipped pipettes. Respective layers of specimen aliquots were pooled, mixed, and volune nieasured. Recovery of sample volume was calculated. Assays and electrophoresis were repeated on the fractions and electrophoresis for isoenzymes was done. All samples were held at $6^{\circ}$ until analyses were completed. To facilitate handling, Fraction III was diluted prior to assay with saline to approximately $80 \mathrm{mg}$ protein per $\mathrm{ml}$.

\section{Analytic methods}

Total protein was determined by a biuret method" calcium and magnesium by atomic absorption spectrophotometry ${ }^{3}$. SGOT and LDH activities were determined by the spectrophotometric methods of Steinberg ${ }^{4}$ and Wacker ${ }^{5}$, respectively, CPK by the fluorometric method of Sax and Moore ${ }^{6}$. Values were calculated when possible into percentages of total constituent distributed among the three fractions.

Paper electrophoresis of protein was done in a Spinco Model $\mathrm{R}^{*}$ system. The stained paper strips were scanned on an Analytrol". Lipoprotein separation was made in the same system (roo V, I8 h), using an albumin-EDTA-barbital buffer ${ }^{8}$. The paper strips, stained by Oil Red $O$, were evaluated visually. Fractions II and III of six normal and seven muscular dystrophy sera were subjected to horizontal starch gel electrophoresis ${ }^{9}$ conducted at $\mathrm{I}^{\circ}, 20 \mathrm{~h}, 200 \mathrm{~V}$, for SGOT; $\mathrm{I} 7 \mathrm{~h}, 300 \mathrm{~V}$, for CPK. Gels were trimmed to remove surface effects ${ }^{10}$, and segmented at I-cm intervals. Gel segments were macerated in enzyme reaction buffer for SGOT ${ }^{11}$, and in buffered substrate for CPK. The slurries were centrifuged briefly at $2000 \mathrm{rev} / \mathrm{min}$ and assay for enzyme was continued on the clear supernatant fluids. Stained strips of LDH separations of the same specimens on agar gel ${ }^{12}$ were scanned at $55^{\circ} \mathrm{m} \mu$ on the Analytrol. Activities (in appropriate units) of all specimens of a kind were summed for each location, an average taken, and average activity plotted as a line graph against location.

\section{RESULTS AND DISCUSSION}

\section{Reproducibility of fractionation procedure}

Reproducibility of separation was verified by centrifuging paired aliquots of the same serum on two successive days and a single aliquot on the third, and by comparing distribution of protein, calcium, and magnesium in the replicates. Reproducibility of protein constitution was studied by paper electrophoresis of the replicated fractions. No appreciable sample loss occurred during fractionation since 96 to $100 \%$ of sample volume in all specimens studied was recovered in the sum of fraction volumes. Observed distribution of volume, calcium, and magnesium among the replicated fractions of a single serum was highly reproducible, varying no more than $\pm 2 \%$ both within the day and from day to day. Although protein distribution of

* Spinco/Beckman Instruments, Palo Alto, Calif.

Chin. Chim. Acta, $20(1968) \times 73-180$ 
Fractions II and III varied as much as $\pm 5 \%$ day-to-day, electrophoretic study of these fractions in replicate showed that proportional quantities of protein species were reproduced almost identically. Level of reproducibility of calcium values for Fraction I in our study agreed exactly with that reported by Breen and Freeman ${ }^{1}$. We therefore concluded that differences observed between specimens were not likely to be due to inconsistencies of fractionation.

\section{General characteristics of fractions}

Fraction I, the top layer of centrifuged sample, was a watery, frequently opalescent liquid, usually colorless but occasionally faintly yellow. Breen and Free$\operatorname{man}^{2}$ describe this fraction as clear, protein-free by a biuret reaction, and representing 22 to $33 \%$ of the volume centrifuged. We found Fraction I contained traces of protein (Table I), in greater volumes. On paper electrophoresis, all specimens showed a faint staining reaction in the $\beta$-globulin position, and occasionally a pale but distinct band in the albumin position; these visible reactions did not provide calculable peaks by densitometry.

TABLE, I

PROTEIN CONSTITUTION OF FRACTIONS

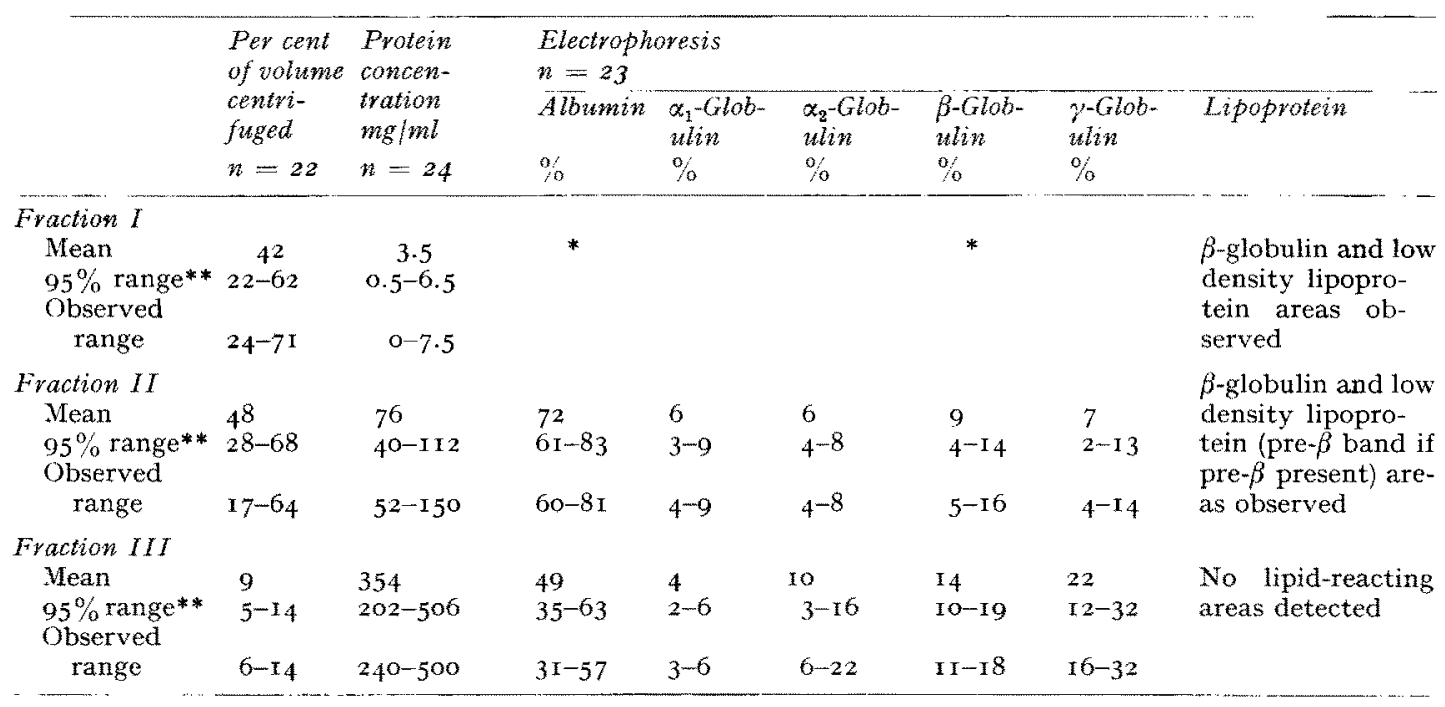

* See text.

** $95 \%$ range $=$ mean $\pm 2 \mathrm{~S} . \mathrm{D}$.

The middle layer, Fraction II, was slightly viscous, varying from pale to dark yellow in color; it was rarely opalescent. In 23 of 24 specimens studied, protein concentration fell between 5.2 and $9.2 \mathrm{~g} \%$; Breen and Freeman ${ }^{1}$ reported protein concentration 2 to $3 \mathrm{~g} \%, 80 \%$ of which was albumin, by moving boundary electrophoresis. We found on paper electrophoresis approximately two thirds of the protein migrating as albumin. Lipoprotein pattern in most instances showed the same pattern as the corresponding whole serum. When pre- $\beta$-globulin appeared in the whole serum pherogram, it also appeared in the derived Fraction II pattern. One specimen, however, exhibited its pre- $\beta$ component in Fraction I. 
Fraction III, the bottom layer, was brown, gelatinous, and very rich in protein. Approximately one fifth the protein was $\gamma$-globulin; lipoprotein electrophoresis showed no lipid-reacting areas. Breen and Freeman ${ }^{1}$ reported a volume of 22 to $33 \%$ of the total for this fraction. Discrepancies between their and our work may be attributable to nature of the specimen since they employed heparinized plasma. We had found plasma fibrinogen blurred electrophoretic separations and precipitated in flakes and threads, particularly in Fraction III.

\section{Recovery of serum components in fractions}

Recovery of protein, calcium, and magnesium content and of LDH, SGOT, and CPK activity in $\mathbf{I} 4$ fresh whole sera was calculated from the summed values of their derived fractions. Pattern of recovery of each constituent is shown in Fig. I.

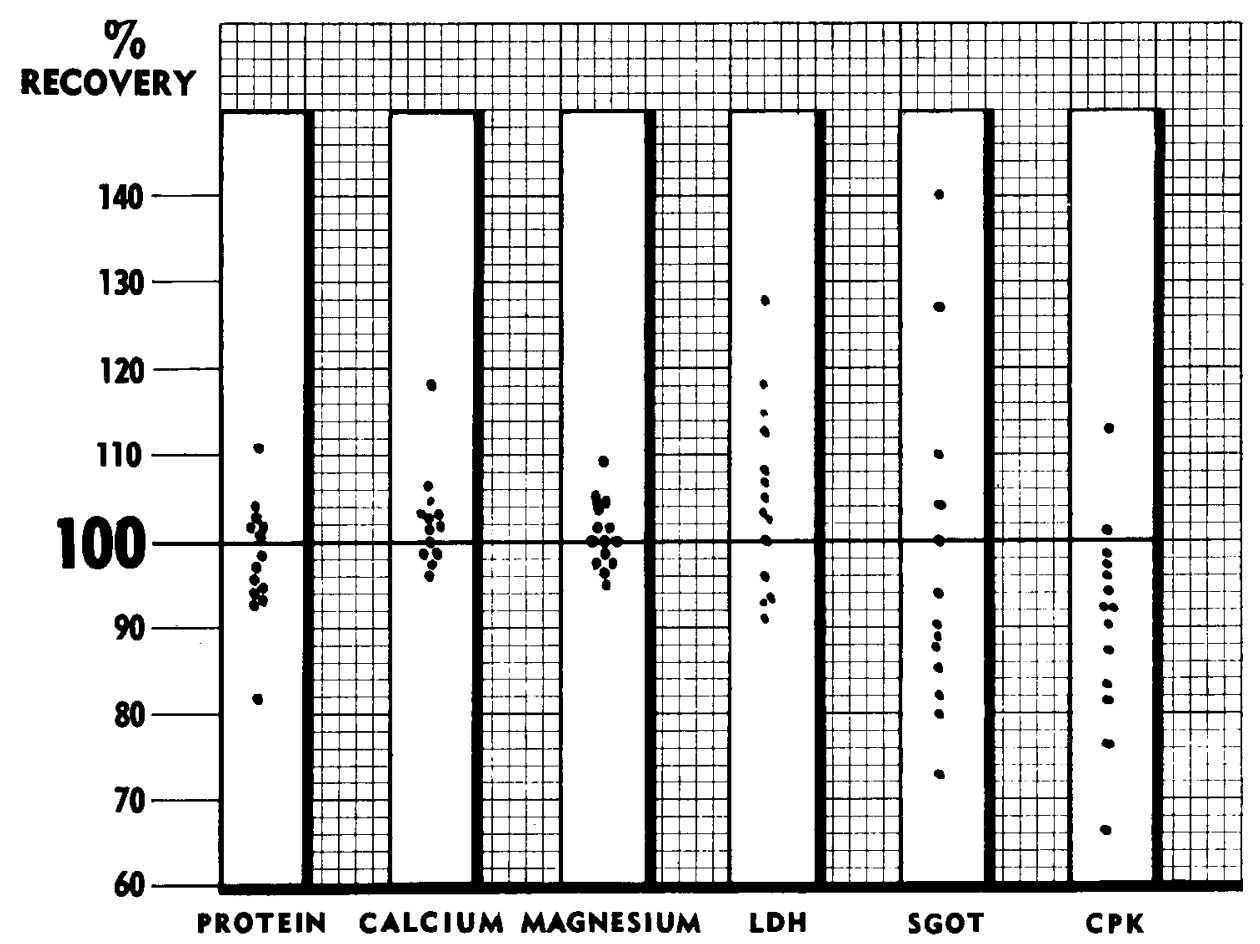

Fig. I. Recovery patterns of components in fractions.

As anticipated, protein, calcium, and magnesium were recovered very well. CPK activity was lost but to a lesser extent than one would expect from reports of Nuttall and Wedin ${ }^{13}$ and Dawson and Fine ${ }^{14}$ on whole serum and muscle extract, respectively. A trend toward over-recovery shown by LDH may be a reflection of an activation process described by Cohen and Larson ${ }^{15}$. The extreme variability of SGOT survival, puzzling in view of reports of its stability in serum ${ }^{4,16}$, may be an artifact arising from summation of inherent error of low-level assay values. Elimination of five specimens, whose whole serum activity was less than 20 units $/ \mathrm{ml}$, from the diagram of Fig. I would, in fact, give an impression that SGOT stability is no 
better than that of CPK. Degree of recovery of LDH, SGOT, and CPK in fractions showed no relationship to normal or abnormal designation of corresponding whole sera.

Enzyme distribution and specific activity in fractions

Mean percentage distribution of protein and enzymes among the fractions was calculated from values of all specimens studied and has been shown in Fig. 2. Distribution of enzymes did not parallel protein distribution; SGOT and CPK distributions

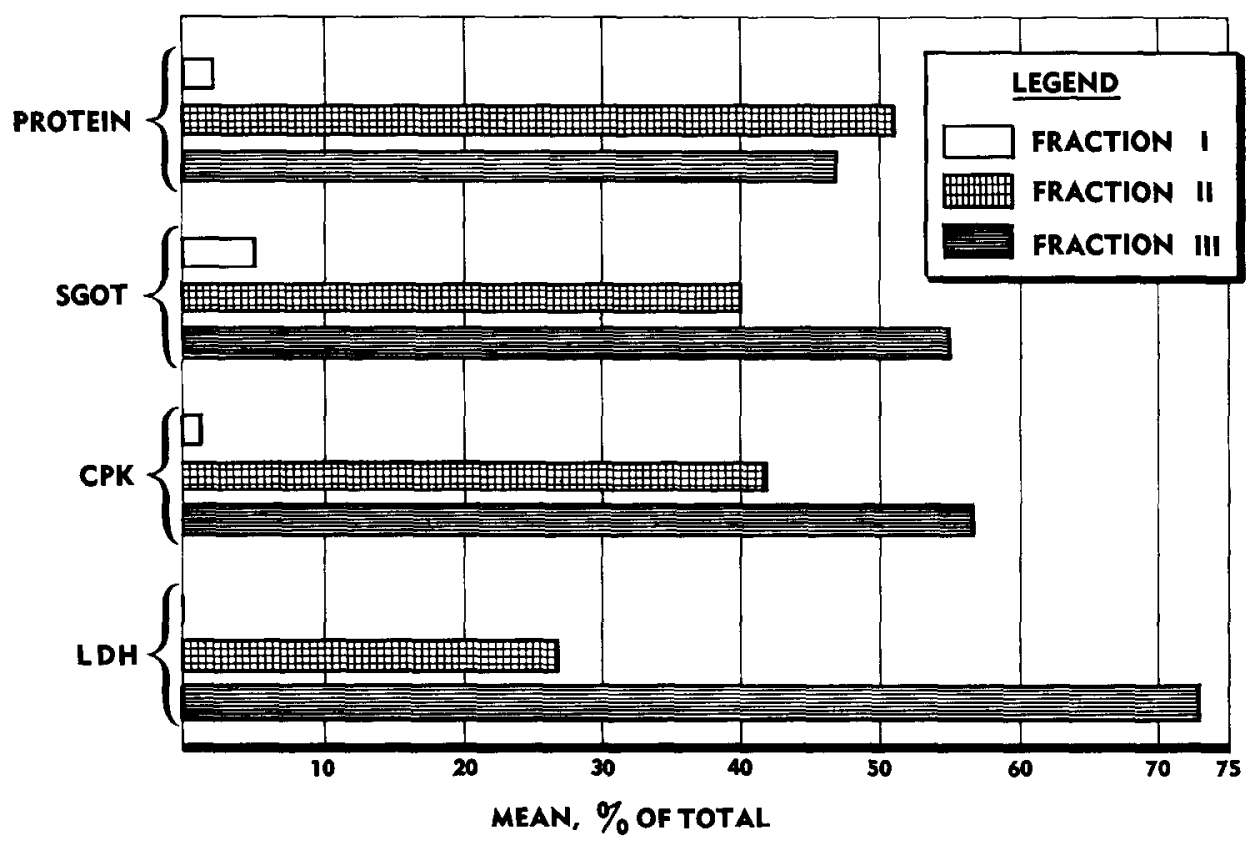

Fig. 2. Distribution of protein and enzymes in fractions.

are comparable, but that of LDH differs from both, as may be expected in view of the accepted estimates of molecular weights of these enzymes. Although distribution figures for Fraction $I$ of normal and abnormal specimcns appcared to indicate greater SGOT activity in normal than in abnormal fraction, examination of actual unit values showed an average of only 2 units $/ \mathrm{ml}$ of Fraction I, whether normal or abnormal in origin. In a calculation of percent distribution by fraction, such values assumed greater significance when related to the low total activity of normal specimens than when related to considerably higher activities of abnormal specimens. SGOT unit values in Fraction I correlated with neither the occurrence nor amount of protein found, and, in a majority of instances, were most probably non-specific reflections of spectrophotometer instability and reagent variables.

Mean and ranges of specific activity of $\mathrm{LDH}, \mathrm{SGOT}$, and $\mathrm{CPK}$ in Fractions II and III have been tabulated in Table II. Fraction I, consistently protein-poor and frequently lacking detectable enzyme activity, was not considered. Specific activity of Fraction III was regularly greater than that of Fraction II in both normal and 
TABLE II

SPECIFIC ACTIVITY OF ENZYMES IN FRACTIONS

Units enzyme per milligram protein.

\begin{tabular}{|c|c|c|c|c|c|c|}
\hline \multirow{2}{*}{$\begin{array}{l}\text { Enzyme } \\
\text { Fraction }\end{array}$} & \multicolumn{2}{|l|}{$L D H$} & \multirow{2}{*}{$\frac{S G O T}{I I}$} & \multirow[b]{2}{*}{$I I I$} & \multirow{2}{*}{$\begin{array}{l}C P K \\
I I\end{array}$} & \multirow[b]{2}{*}{$I I I$} \\
\hline & $\overline{J I}$ & 111 & & & & \\
\hline \multicolumn{7}{|c|}{ Normal sera $(n==11)$} \\
\hline Mean & 0.41 & 1.21 & 0.23 & 0.55 & 0.30 & 0.54 \\
\hline Observed range & $0.16-0.83$ & $0.24-2.20$ & $0.07-0.5^{8}$ & $0.15^{-2.10}$ & $0.14-0.62$ & $0.24-1.07$ \\
\hline \multicolumn{7}{|c|}{$\begin{array}{l}\text { Muscular dystrophy sera } \\
\qquad(n=7)\end{array}$} \\
\hline Observed range & $0.38-3.32$ & $0.52-10.4$ & $0.32-1.55$ & $0.47-3.18$ & $2.08-37.2$ & $1.72-50.8$ \\
\hline
\end{tabular}

abnormal specimens. Taking into consideration those exceptions excused by the known variation of enzyme level with stage of the disease process, abnormal serum fractions showed greater specific activities than corresponding fractions of normal sera.

\section{Isoenzymes}

Electrophoretic separation of LDH, CPK, and SGOT activity in Fractions II and III has been illustrated in Figs. 3, 4, and 5. Both Fraction II and III of normal and abnormal serum exhibited (Fig. 3) the five areas of LDH activity customarily observed in whole serum. Slight quantitative differences occurred between the fractions, the greatest appearing in $\mathrm{LDH}_{2}$, which appeared more concentrated in Fraction II than in Fraction III. Significant difference between normal and muscular dystrophy fractions occurred only in $\mathrm{LDH}_{1}$ of Fraction II, where the mean density value of muscular dystrophy specimens is $13 \%$ less than that of normal.

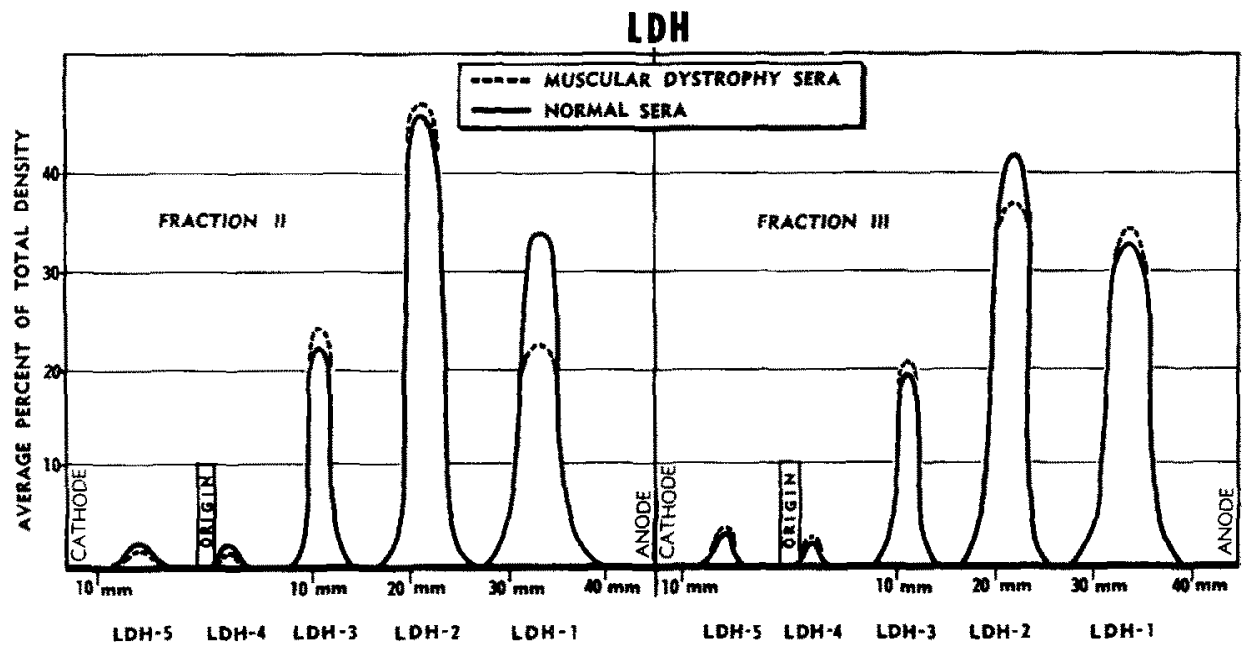

Fig. 3. Agar gel electrophoretic separation of LDH isoenzymes of normal and muscular dystrophy Fractions II and III ( $\mathrm{r} 2 \mathrm{~mA}$ per strip, $\mathrm{t} h, \mathrm{pH} 7-5$ ).

CPK activity of fractions of normal serum was barely detectable and occurred across the starch gel slab in a nondescript smear (Fig. 4). Activity of muscular Clin. Chim. Acta, $20(1968)$ 173-180 


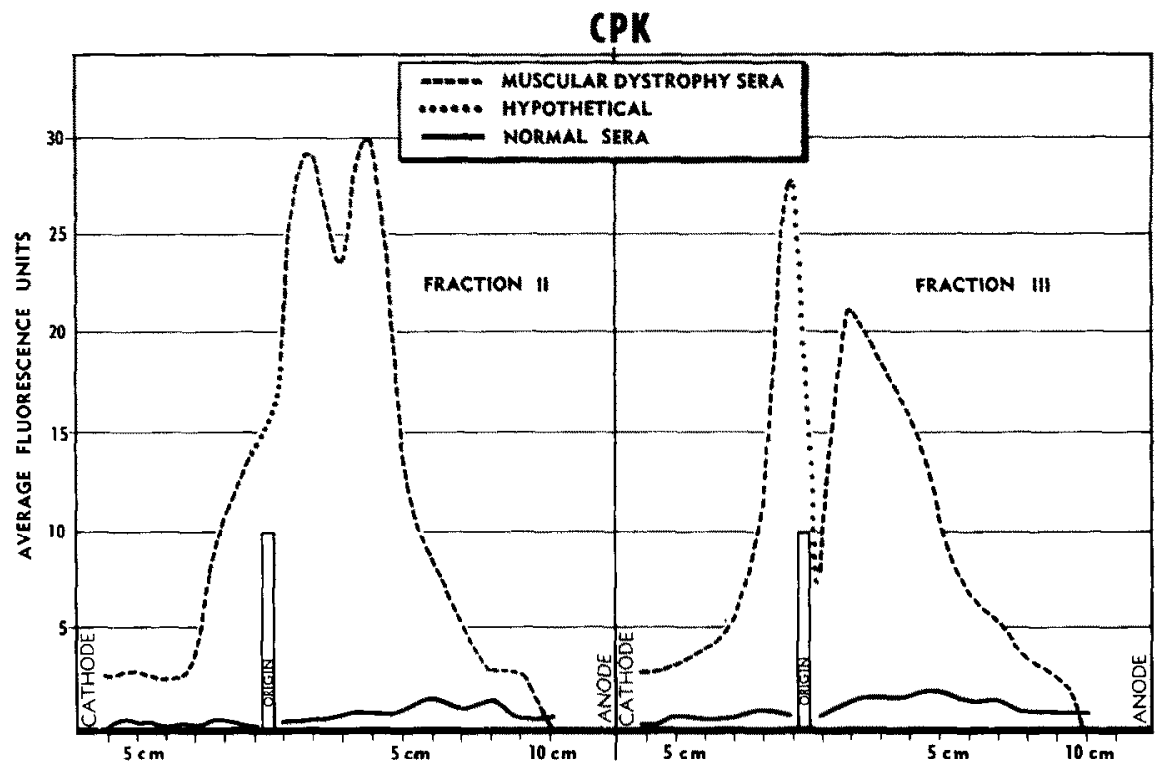

Fig. 4. Starch gel electrophoretic separation of CPK activity of Fractions II and III of normal and muscular dystrophy sera (300 V, I $7 \mathrm{~h}, \mathrm{pH} \mathrm{8.6)}$.

dystrophy fractions was greatly increased over the normal; Fractions II and III had very dissimilar patterns. Muscular dystrophy whole sera, examined by the same technique, showed patterns similar to either Fraction II or Fraction III. Experiments with a discontinuous buffer system ${ }^{17}$ have indicated a compact anodic peak, located 7 to $10 \mathrm{~cm}$ from the origin, in whole abnormal serum, abnormal fractions, and normal heart and skeletal muscle homogenates. Although areas of activity in inmediate proximity to the insertion still occurred with the discontinuous system, they were much more discrete and much less pronounced. The experiments suggested that the isoenzyme pattern of CPK could have been better evaluated by starch gel technique in conjunction with discontinuous, rather than borate-borate, buffer system.

The bulk of SGOT activity in Fractions II and III (Fig. 5) was anodic. Although the undulant form of normal fraction patterns and shouldered peaks of abnormal patterns might appear to imply a number of isoenzymes, experiments with discontinuous buffer, staining in situt ${ }^{18}$, and blank analysis of gel segments on normal and abnormal whole serum and fractions, and on normal heart and skeletal muscle homogenates, seemed to indicate essential homogeneity of the anodic peak, and absence of any other areas of activity in whole serum and its fractions.

\section{ACKNOWLEDGMENTS}

This work was supported in part by grants from Muscular Dystrophy Associations of America, the Indiana Heart Association, and the United States Public Health Service (\#AM 0290I).

The authors are indebted to Mr. K. John Jarrett, University of Michigan, and to Mrs. Roberta Lesh, Caylor-Nickel Research Foundation, for able technical assistance. 


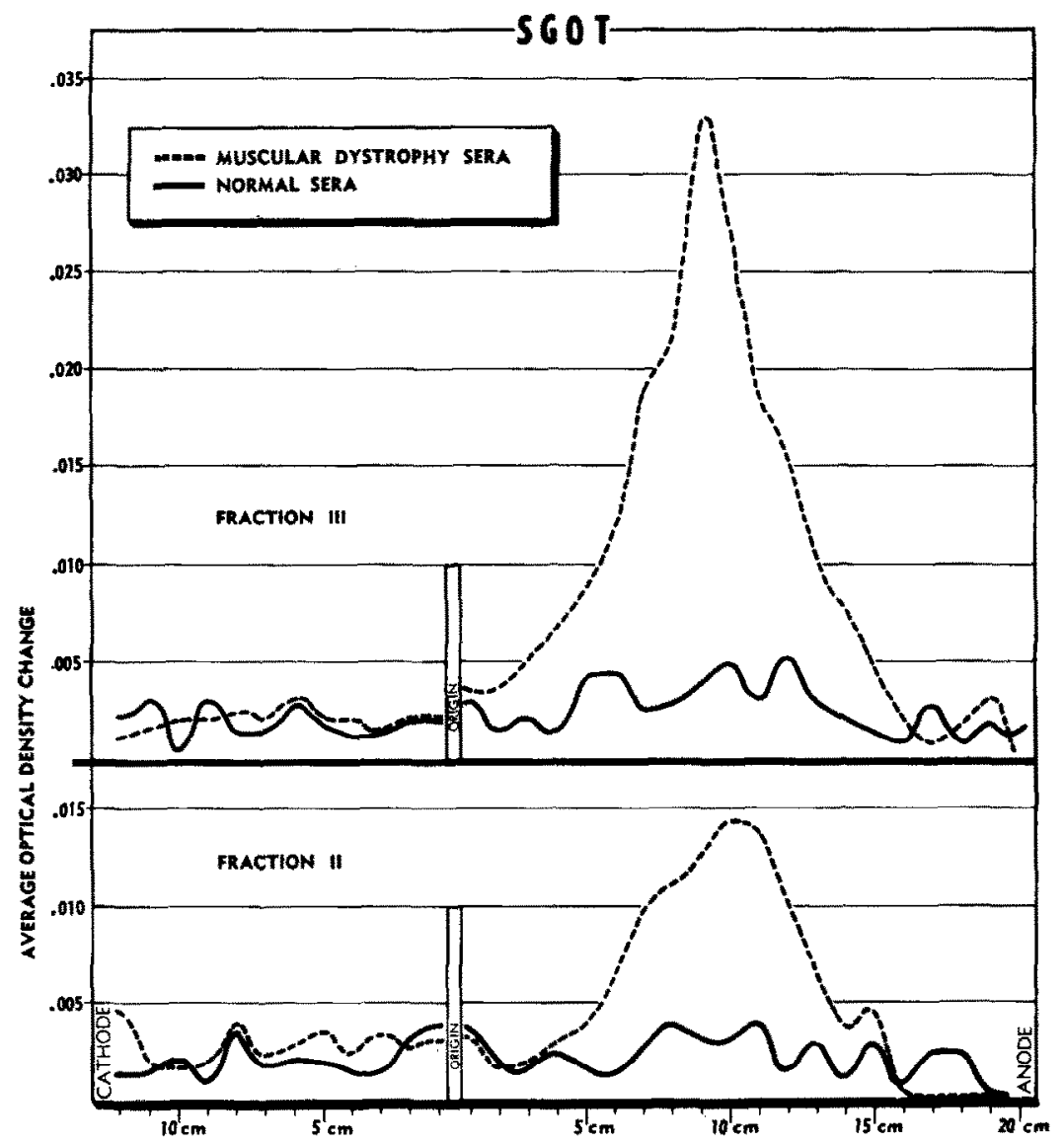

Fig. 5. Starch gel electrophoretic separation of SGOT activity of Fractions II and III of normal and muscular dystrophy sera $(200 \mathrm{~W}, 20 \mathrm{~h}, \mathrm{pH} 8.6)$.

\section{REFERENCES}

I M. Breen and S. Freeman, Clin. Chim. Acla, 6 (rg6i) isi.

2 T. E. Weichselbaum, Am. J. Clin. Pathol., I6 (1946) 40.

3 Perkin-Elmer Corporation, Norwalk, Connecticut, Technical Bulletin (supplement, Nov. I966; supplement, Jan. 1964) Calcium, I and 8; Magnesium, I and 9.

4 D. Steinberg, D. Baldwin and B. H. Ostrow, $f$. Lab. Clin. Med., 48 (1956) I 44.

5 W. E. C. WACker, D. D. Ulmer and B. L. VALLEE, N. Engl. J. Med., 255 (I956) 449.

6 S. M. SaX and J. J. Moore, Clin. Chem, I I (I965) 95 I.

7 Spinco/Beckman, Fullerton, California. Procedure B in Model $R$ Paper Electrophoresis Instrutction Manual, RIM-5, n.d.

8 R. S. LEES AND F. T. Hatch, f. Lab. Clin. Med., 61 (1963) 518.

9 O. Smithies, Advan. Protein Chem., I4 (r959) 65.

io J. W. White, Jr. and I. Kushnir, Anal. Biochem, í (I966) 302.

11 W. D. Block, R. Carmichate and C. E. Jackson, Proc. Soc. Exptl. Biol. Med., I 5 (I964) 941.

12 E. J. Wright, L. P. CaWley and L. Eberhardu, Am. J. Clin. Pahol., 45 (1966) 737.

13 T. Q. Nuttall and D. S. Wedin, $J, L a b . C l i m, M e d ., 68$ (I966) 324 .

I 4 D. M. DAWSON AND 1. H. Fine, Arch. Neurol, 16 (1967) 175.

15 L. Cohen and L. Larson, $N$. Engl. $J$. Med., 275 (rg66) 465.

16 A. Karmen, F. Wroblewski and J. S. LaDue, J, Clin. Invest, 34 (1955) I 26.

17 M. D. Poulik, Native, 180 (1957) 1477.

18 L. E. Decker And E. M. Rau, Proc, Soc. Exptl. Biol, Med., II2 (1963) I44. 